\title{
Engaging students in enhanced academic transitions - a case of online study skills resource SPICE (Student Pre-arrival Induction for Continuing Education)
}

\author{
Dr Monika Foster \\ Edinburgh Napier University, UK
}

\section{Abstract}

A traditional induction may not always be best suited to the needs of increasingly diverse student groups on study programmes. Research shows (Cook et al., 2006; Burley et al., 2009; Shofield and Sackville, 2006) that an extended induction which allows for a steady development of skills is more suitable for international and direct entry college students. Additionally, there is evidence that students respond well to new technologies that allow for a more interactive and relationship-building approach (Pringle et al., 2008), while learning from peers seems to help engage new students in learning (Lowe and Cook, 2003).

This case study introduces online study skills resource 'SPICE' (Student Pre-arrival Induction for Continuing Education) designed to assist international students and students coming as direct entry students from colleges to the university. It provides a rationale for the development of the resource and examples of some of its features. The study then attempts to evaluate the effectiveness of the resource through feedback from students and tutors, and offers suggestions for further development of the resource.

Keywords: induction; online; study skills; international students.

\section{Introduction}

One of the major drives for initiatives such as SPICE (Student Pre-arrival Induction for Continuing Education), which is the subject of this study, is the rising proportion of 
international students entering UK Higher Education (HE) and the impact on the support for students pre-arrival and during study in the UK. UK Higher Education Institutions (HEIs) have been attracting increasing numbers of international, non-EU students to study on both undergraduate and postgraduate programmes, including collaborative programmes overseas. According to the latest HESA figures, $10.5 \%$ of all students in higher education in the UK were international students (HESA, 2010). Students from China and India accounted for nearly one third of all non-EU domicile students at UK HEls in 2008/9, with Indian students' numbers increasing by 31.5\% in 2008-2009 (HESA, 2010).

\section{Needs of international students}

There has been a fair amount of research with these two groups of students to inform programme designers and tutors, particularly in respect of how former educational experiences affect the way students engage with the new learning and teaching environment. Patricia and Dawson's research in 2004 with Chinese and Indian students on postgraduate programmes at Thames Valley University, London, points that Chinese students are educated in a non-interactive environment, where they are expected to master the knowledge and present it at examinations with little interaction built in the courses of study (Patricia and Dawson, 2004). The students are used to all materials being laid out by the tutor, usually with one textbook per subject and expect the tutor/university to take responsibility for leading learning. Similarly, research with Indian students at Sheffield Hallam University (Burley et al, 2009) reveals a gap between an expectation of independent learning from students in UK HE and the study habits students bring with them, such as an emphasis on rote learning and limited skills to enquire, synthesise and present knowledge. This indicates that it is crucial not only to recognise the study skills students bring on arrival to the UK but to use this knowledge to develop new skills which are crucial for successful study on programmes in UK HE.

\section{Extended induction}

With steadily growing numbers of non-EU students, many coming on short courses (e.g. one year long) through articulation agreements, it seems vital to ensure that the students blend well into the UK education system through effective and meaningful induction. This leads to the second drive for the development of SPICE which is based on emerging trends in supporting students during induction. 
Increasingly, attention is given to a wider context of transition from one academic context to another, rather than an induction event at the start of the programme. Shofield and Sackville (2006) view induction as having three parts: academic, social and administrative. Cook et al. (2006) propose 'extended induction' which is about 'a longer assimilation of new students into the ways in which the institutions operate' (Cook, 2006, p.7). Furthermore, Huczynski and Buchanan (2007) propose induction as a three stage socialisation process including pre-arrival, encounter and metamorphosis stages. Research on induction by White and Carr (2005) found that, at the encounter stage, social integration may be slow which may impact on the metamorphosis stage when students do not feel a sense of belonging to the programme group. This in turn may block the key intention of induction, which is to welcome and help students adapt.

\section{Use of technology in induction}

Technology offers the opportunity to meet some of these shortcomings. Online induction can help see induction as a process, not as an event. Palloff and Pratt (2007) believe the aim of the induction process is to maximise the educational potential for both the online classroom and online student. Lowe and Cook (2003) recognise that induction is 'a process instead of an event and should be designed to promote peer group and staff/student interaction as well as academic preparation' (Lowe and Cook, 2003, p.75). In this view, induction allows for learning communities to be built and evolve, familiarise the students with the 'new rules' and get a feel for UK higher education (Murphy, 2008).

\section{Examples of web based inductions}

In the University of Glasgow, Pringle et al. (2008) aimed to develop web-based material to support international students prior to and during the study. The findings from focus groups with students who used the materials indicated that students benefited from them, mainly as an opportunity to compare expectations about learning and teaching and the reality. The materials allowed students to consider changes to their own learning styles prior to transition to the University of Glasgow. The University of Southampton developed an 'Arrive UK' induction course that has been offered to students since 2005 (Watson, 2008). 'Arrive UK' is delivered for five weeks prior to study at Southampton and it utilises a range of technologies. It is developed using the virtual learning platform, Moodle. It includes a variety of podcasts and videos which can be downloaded by the students. 


\section{Summary}

An extended induction which recognises students' prior learning and teaching background, takes care of students' expectations and the development of effective, academic study skills is proposed in response to growing numbers of students from overseas. It can be greatly enhanced by technology which offers an opportunity to build a relationship with the student. Additionally, students' perspective, for example from their peers who have already experienced study in the UK, helps personalise the induction and appeal to new students.

\section{The challenge}

In 2008/9, 24\% of students at Edinburgh Napier University were international and from more than one hundred countries. The top two countries students came from to study at Edinburgh Napier University were China (1,609 students) and India (644 students) (Edinburgh Napier University, 2008). Edinburgh Napier has also more than 1,200 students studying overseas through collaborative partnerships with institutions such as City University in Hong Kong (Edinburgh Napier University, 2007).

The university addresses the issue of a diverse student population on their programmes through staff conferences to disseminate good practice and projects like SPICE to explore new, innovative ways of supporting students in academic transition. The need for a prearrival induction was identified on the BA Hospitality Management programme. The course has large numbers of direct entry Indian students (approximately 100+ per year). Students on the programme come from colleges in India as direct entry students to third year. They encounter a number of challenges related to the differences in academic cultures, different sets of expectations of university students in the UK and living, and studying in a new country. As the students typically spend just under a year in the UK, the standard induction is too short, happens too late (post-arrival) and cannot address the breadth of the new skills and awareness that need to be assimilated by the students. Another challenge is a cultural preference to rely on peers who already study in the UK to provide academic and pastoral support rather than utilising central university support and information available during induction and study in the UK. 


\section{Aims}

The aim of the project was to enhance induction by developing early skills and awareness before study in the UK. Furthermore, it was to engage students in the process of transition to a new learning environment by using peer voice and providing tasks which make students reflect on their study habits and prepare for the requirements of study in the UK.

\section{Engaging students}

An underlying principle to achieve the above aims and objectives was to work closely with the students to ensure the outcome is appealing to new students and welcoming them to their new learning and teaching context. According to Edward (2003), for students to succeed in their education, they must be 'motivated, accustomed to the university culture and feel part of the university community' (Edward, 2003, p.223).

There were two ways students were involved in the SPICE project: through individual and group interviews with students already studying at Edinburgh Napier University (altogether over 70 students) and through focus groups with students in India preparing to arrive to the UK (altogether 56 students).

Below are examples of what students in Edinburgh said on the following topics.

Contact hours (used to underpin activities in 'Are you ready for University?' part):

In India, the college starts at 8 , ends by 6 pm so we have $10-12$ hours of college course a day so you go on studying and getting things in your head. But here, the programme, if students come 6-9 hours a week, that's enough, sufficient to give you knowledge, give you the basic idea to give you the degree. (In India) We need the knowledge in, all we need is the knowledge you get into your head, that's it. And here, I was first confused, you should have the initiative, you should take the initiative, you should have the courage to go about it and show your knowledge. 
Approach to study (used to underpin a section 'Time a precious resource' in 'Edinburgh Napier study skills' part):

It is a major leap for students coming from India. They come here to work and to study, these are the 2 aims. Okay, but their priority lies with work - I know the priority should be study. You get the opportunity to work and that's good, but you can't make that your priority, the priority is study. If you forget that, that's wrong. You can't forget that, you can't skip lectures and tutorials like that and go on and on.

The value of using of WebCT ITime management (intranet) (to be included in 'Using available resources' in 'Edinburgh Napier study skills' part):

(Differences in IT use for study in India) Actually in India, we used not even 30\% of IT for study. It is more formal there but not very practical. Because your tutors give you everything and you see them all the time, no need to use IT a lot. Here you have to use IT to know what's happening and do your assessment. Also, it saves you time to ask questions or wait until someone tells you. So IT helps you, it's beneficial once you learn how to use it a lot.

Working in groups (to underpin section 'Working with others' in 'Edinburgh Napier study skills' part):

(About differences in working in groups) We have little experience of working in groups and, even if we do, it's quite informal only, for talking about something. Here, the groups have a specific task, they are professional, they are formally run. So that's quite different, but you need to learn how to do it, how to work in a group. Otherwise, you can be very disappointed and disappoint others.

Assessment (used for section 'Giving credit where it's due' in the 'Academic Writing' part):

The first assessment here is the first time I did anything like this, writing an essay or a report, analysing literature, writing a case study. I don't know how I am supposed to go about it, and what will be the marks, and if I fail, what happens then. So, this made me very nervous and confused. 
In India, we didn't use the reference rule that much. First time you do it, you need to take a lot of time with every sentence, how do you need to give your reference, and what needs to be done to do it well.

A selection of student voices was included in the resource to help new students identify themselves with the new experience and to emphasise the message 'this is what happened to me and I used the following strategies to overcome it, you can do it too!'.

The resource was piloted with students in India who were preparing to come to Edinburgh Napier in the following year. During focus groups, students discussed the activities and described their hopes and fears about study abroad and what they think may be useful for them. Some of the comments from the focus groups are included below:

We know little about what is awaiting for us in Edinburgh so this is very useful for us to make us less anxious.

The change from what we do now is going be very big but we know our colleagues who are in Edinburgh now did this and they do well so it makes us feel better about trying ourselves.

A lot of the activities are completely new to me, I want to know more about them and how to do well at Napier.

The students in India noted that the student voices were more detailed in their account of studying and living in Edinburgh, and more focused on the academic skills than the advice they tend to get from their peers.

\section{Outcomes}

The outcome of the one and a half year project is a pre-arrival induction resource. SPICE is driven by students sharing their experiences with their peers so 'by students and for students' is very much the motto of the resource. SPICE was partially funded by TESEP (Transforming and Enhancing the Student Experience through Pedagogy) and partially by internal faculty funding at Edinburgh Napier University. The pilot project was developed for 
$3^{\text {rd }}$ year direct entry Indian students on the BA Hospitality Management programme. It has now been used by two cohorts of students in India ( $n=387$ students) studying on the Edinburgh Napier programme. SPICE content has been structured into four strands as illustrated below in Figure 1.

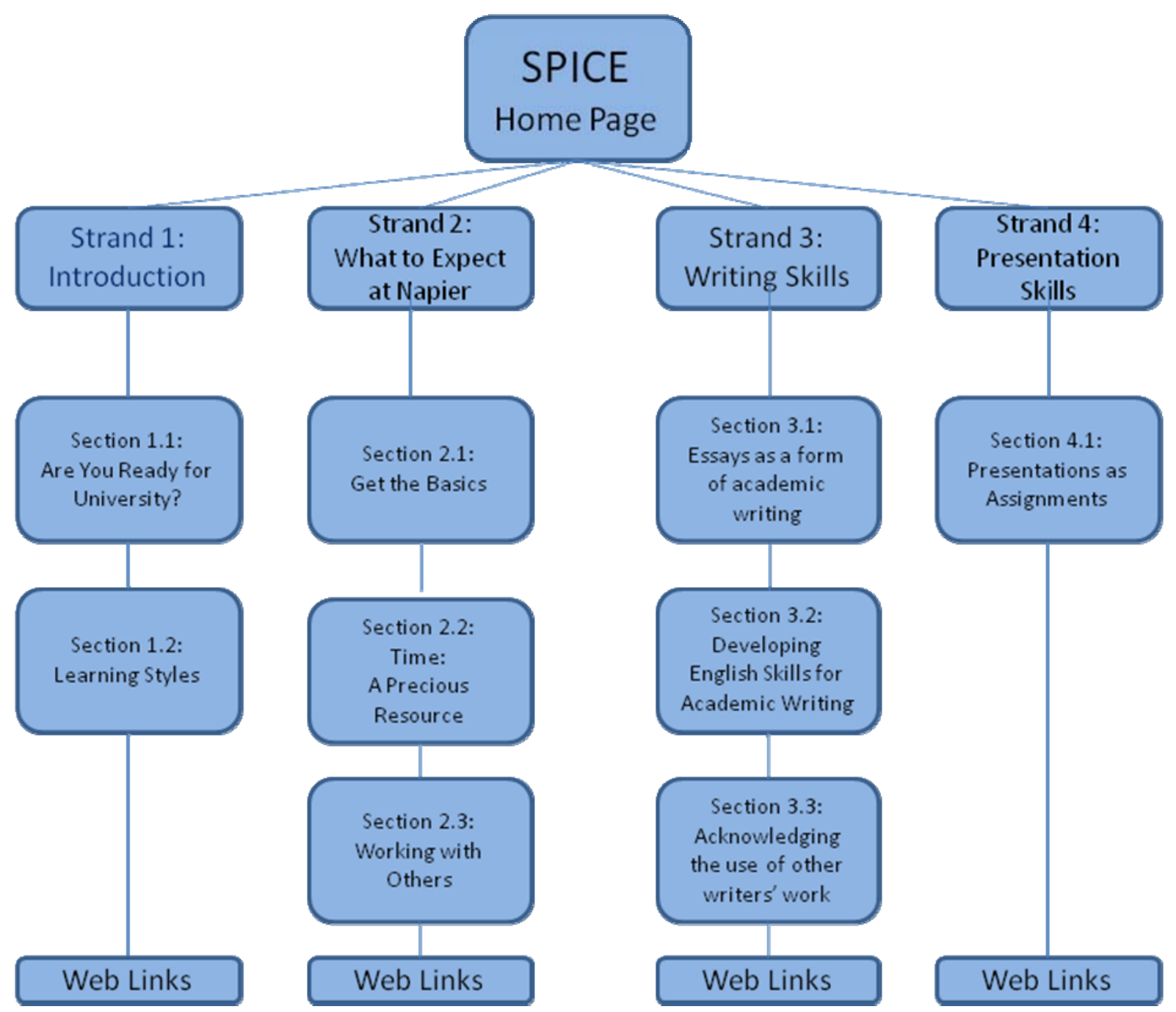

Figure 1. Structure of SPICE.

SPICE includes an introduction to being a university student in the UK; key academic study skills including planning, time management, team work, individual work, library skills; academic writing skills including referencing, plagiarism, essay and report writing, case studies; and a selection of activities to enhance presentation skills. Unique features of SPICE include being student and task driven. Upon completing an activity, students receive feedback which is generated automatically from the bank of feedback and answers. The feedback and the comments from the students are used to affirm the student's expectations of the university and direct to the right study habits. Reports on 
students' progress can be generated as well as a detailed overview of activities students failed to complete/undertake. Below are examples of activities from each of the four parts of SPICE:

\section{Are you ready for University?}

\section{What will teaching and learning be like at uni?}

At uni, Sumit found subjects more challenging than at college.

What do you think some of the differences might be at uni? Write your answer in the box then read Sumit's comments below. Then move on to the second part of the activity.

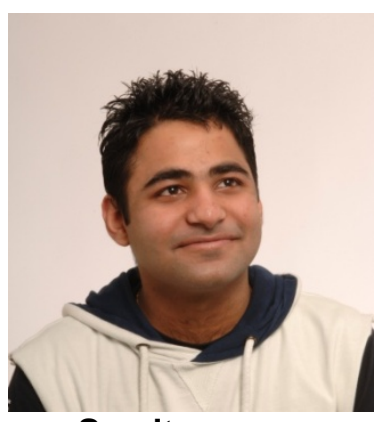

Sumit says ...

"I think self study is very important over here, because essays are all about your self-study. It's all what you have learned and you have to show that you have learned that thing. So if you have done a self study, and you see the past essays, if you talk to your lecturers then you succeed. I feel lucky I've been to a UK university that has lecturers more flexible than lecturers in India. You can approach them at any time and they are ready to help you. They help me a lot."

\section{Edinburgh Napier study skills}

\subsection{Forward planning for uni study}

Here is an example of a typical timetable for a college student studying in India.

\begin{tabular}{|c|c|c|c|c|c|c|c|c|c|}
\hline & $\begin{array}{l}\text { 9am- } \\
\text { 10am }\end{array}$ & $\begin{array}{l}\text { 10am- } \\
\text { 11am }\end{array}$ & $\begin{array}{l}11 \mathrm{am}- \\
12 \mathrm{pm}\end{array}$ & $\begin{array}{l}12 \mathrm{pm}- \\
1 \mathrm{pm}\end{array}$ & $\begin{array}{l}1 \mathrm{pm}- \\
2 \mathrm{pm}\end{array}$ & $\begin{array}{l}2 \mathrm{pm}- \\
3 \mathrm{pm}\end{array}$ & $\begin{array}{l}3 p m- \\
4 p m\end{array}$ & $\begin{array}{l}4 p m- \\
5 p m\end{array}$ & $\begin{array}{l}5 p m- \\
6 p m\end{array}$ \\
\hline Monday & \multicolumn{3}{|c|}{ Classes } & Lunch & \multicolumn{5}{|c|}{ Classes } \\
\hline Tuesday & \multicolumn{3}{|c|}{ Classes } & Lunch & \multicolumn{5}{|c|}{ Classes } \\
\hline Wednesday & \multicolumn{3}{|c|}{ Classes } & Lunch & \multicolumn{5}{|c|}{ Classes } \\
\hline Thursday & \multicolumn{3}{|c|}{ Classes } & Lunch & \multicolumn{5}{|c|}{ Classes } \\
\hline Friday & \multicolumn{3}{|c|}{ Classes } & Lunch & \multicolumn{5}{|c|}{ Classes } \\
\hline Saturday & \multicolumn{3}{|c|}{ Classes } & Lunch & \multicolumn{5}{|c|}{ Classes } \\
\hline Sunday & & & & & & & & & \\
\hline
\end{tabular}

Now look at the typical timetable below for $3^{\text {rd }}$ year direct entry students on the Edinburgh Napier University BA Hospitality Management programme. Each trimester, students undertake 3 study modules, each module having a value of 20 credits. 


\begin{tabular}{|c|c|c|c|c|c|c|c|c|c|}
\hline & 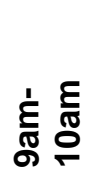 & 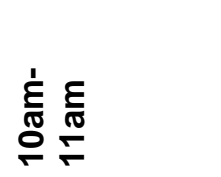 & 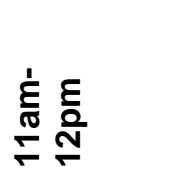 & 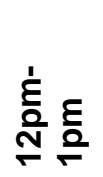 & $\begin{array}{l}\frac{\varepsilon}{2} \\
\stackrel{2}{\frac{2}{2}} \\
\frac{a}{1}\end{array}$ & 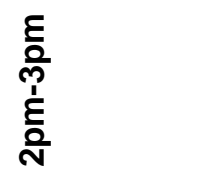 & 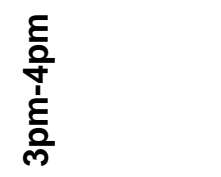 & 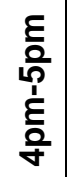 & $\begin{array}{l}\frac{\Xi}{0} \\
\stackrel{0}{1} \\
\frac{1}{2} \\
\text { ம }\end{array}$ \\
\hline ¿ & & $\begin{array}{l}\text { TSM0911 } \\
\text { Hospitality } \\
\text { Business } \\
\text { Development } \\
\text { (Lecture) }\end{array}$ & & & & $\begin{array}{l}\text { TSM09104 } \\
\text { Service } \\
\text { Management } \\
\text { (Lecture) }\end{array}$ & $\begin{array}{l}\text { TSM0911 } \\
\text { Hospitality } \\
\text { Business } \\
\text { Development } \\
\text { (Tutorial) }\end{array}$ & & \\
\hline$\frac{0}{2}$ & & & $\begin{array}{l}\text { TSM09111 } \\
\text { Hospitality } \\
\text { Supervision } \\
\text { \& Training } \\
\text { Skills } \\
\text { (Lecture) }\end{array}$ & & $\begin{array}{l}\text { TSM09111 } \\
\text { Hospitality } \\
\text { Supervision } \\
\text { \& Training } \\
\text { Skills } \\
\text { (Tutorial) }\end{array}$ & & & & \\
\hline ర్d & & & & & & & & & \\
\hline 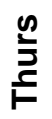 & & & & & & & & & \\
\hline it & & & & \multicolumn{2}{|c|}{$\begin{array}{l}\text { TSM09104 Service } \\
\text { Management } \\
\text { (Tutorial) }\end{array}$} & & & & \\
\hline ڤే & & & & & & & & & \\
\hline 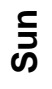 & & & & & & & & & \\
\hline
\end{tabular}

Compare and contrast the amount of teaching time a student gets on a study programme at Edinburgh Napier with the amount received on your course in your college in India. At UK universities like Edinburgh Napier, there is an emphasis on independent learning. A 20-credit module is allocated a notional 200 hours of study. Approximately $\mathbf{6 0}$ of these may be attendance, but the rest - at least $\mathbf{1 4 0}$ hours - is self-directed study. So, for 3 study modules on the $3^{\text {rd }}$ year BA Hospitality Management programme at Edinburgh Napier, you will be expected to give no less than 420 hours of self study per trimester.

So, how many hours of self study do you need to do each week on the BA Hospitality Management programme? Let's do the calculations and see:

Total amount of time a student needs to spend on $\quad 600$ hours -105 hours 495 hours per trimester independent study over a 15-week trimester (based on 7 hours class time per week):

Average amount of time a student needs to spend 495 hours $\div 15$ weeks on independent study each week

33 hours per week

So, the bottom line is that, students need to find time to fit in around 33 hours of self-study time every week during a trimester. That's a lot to fit in, but it gets easier with time!

The next table shows the total amount time each week that you must allocate for class time and study time for each of the 3 study modules. Fortunately, you are able to decide for yourself how and when you want to study, so you can also use your free time in the evenings and on weekends for study if you want to. 

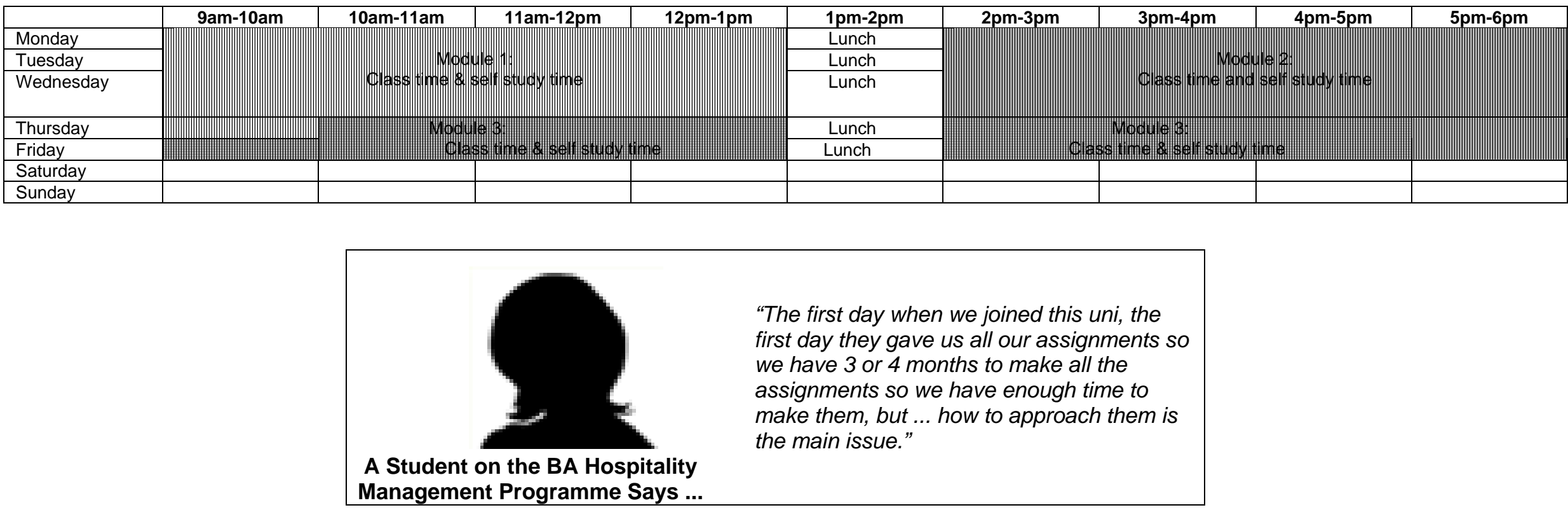

Deadlines, Deadlines, Deadlines!!! This is a typical $3^{\text {rd }}$ year BA Hospitality Management assessment hand-in schedule for Trimester 1.

\begin{tabular}{|c|c|c|c|c|c|c|c|c|c|c|c|c|c|c|c|}
\hline Module Name & Week 1 & Week 2 & Week 3 & Week 4 & Week 5 & Week 6 & Week 7 & Week 8 & Week 9 & $\begin{array}{l}\text { Week } \\
10\end{array}$ & Week 11 & $\begin{array}{l}\text { Week } \\
12 \\
\end{array}$ & $\begin{array}{l}\text { Week } \\
13\end{array}$ & Week 14 & $\begin{array}{l}\text { Week } \\
15\end{array}$ \\
\hline $\begin{array}{l}\text { TSM09101 } \\
\text { Hospitality Business } \\
\text { Development }\end{array}$ & & & & & & & & $\begin{array}{l}2000- \\
\text { word } \\
\text { Essay }\end{array}$ & & & & & & \multicolumn{2}{|c|}{ Exam } \\
\hline $\begin{array}{l}\text { TSM09104 Service } \\
\text { Management }\end{array}$ & & & & & & & & & & & $\begin{array}{l}3000- \\
\text { word } \\
\text { Essay }\end{array}$ & & & \multicolumn{2}{|c|}{ Exam } \\
\hline $\begin{array}{l}\text { TSM09111Hospitality } \\
\text { Supervision \& } \\
\text { Training Skills }\end{array}$ & & & & & & & $\begin{array}{l}2500- \\
\text { word } \\
\text { Case } \\
\text { Study } \\
\text { Report }\end{array}$ & & & $\begin{array}{l}1000- \\
\text { word } \\
\text { Group } \\
\text { Report }\end{array}$ & \multicolumn{3}{|c|}{$\begin{array}{c}\text { Group Delivery of a Training } \\
\text { Session }\end{array}$} & $\begin{array}{l}\text { 1000-word } \\
\text { Learning } \\
\text { Log } \\
\text { Report }\end{array}$ & \\
\hline
\end{tabular}


As you can see, sometimes more than one assessment is due to be handed in around the same time. You'll need to use your 33 hours of weekly study time in different ways at different times for different assessment types required for each of your study modules to make sure that you can meet all your hand-in deadlines on time. Having a degree of flexibility in your weekly schedule is the key, so make sure you leave time for study on your timetable. Do not take a part time job that doesn't allow you to study and prepare for assessments!

\section{Students Say...}

Read what Krish and Kaveri have to say about their assignments and exams...

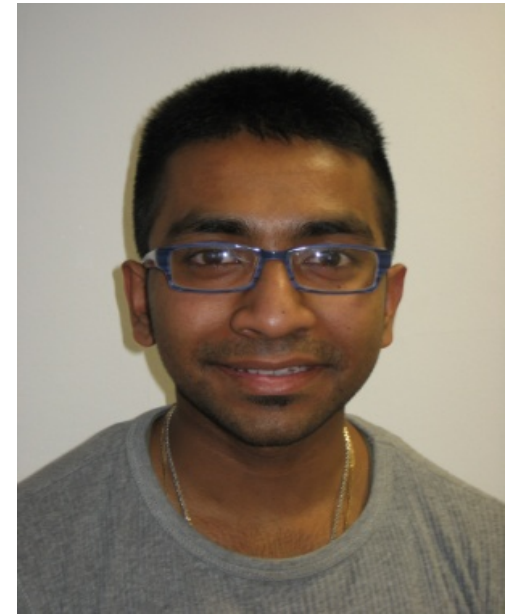

Krish

\section{Kaveri Says:}

"The main thing is just go on reading, reading. The students, most of them, they don't read. ... Read it, if you read it you understand, that's it. And you have sources everywhere, and just write it in your own words you will answer the question, you will make your assignment better, as well as that will benefit your exams. And time is very less here, so that uses your time too. That's the best thing."

\begin{abstract}
Krish says:
"Yes, I had to plan ahead because in India we had to study a lot compared to here. Here, we have maybe one or two exams in two semesters, where in India we have 5 or 6 exams. We have assignments for each and every subject, exams for each and every subject so the pressure is more. Again, you have to plan that out, you have to plan that out but things like sending a rough draft to a teacher. So again, you put everything on the subject of your assignment you still don't know if it's right or wrong."
\end{abstract}

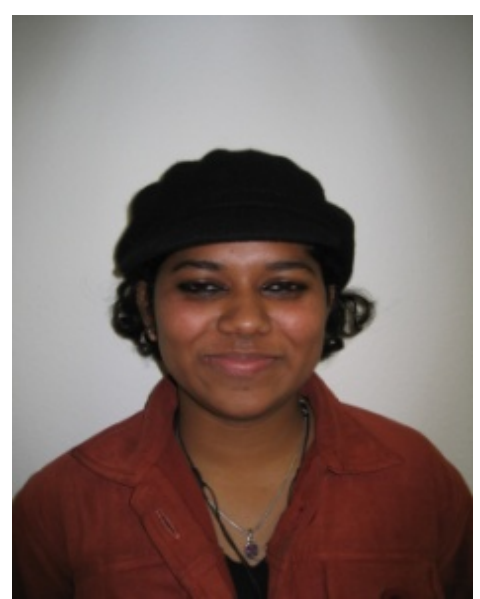

Kaveri

\section{Academic writing skills}

\subsection{Analysing the essay question: Instruction words}

Essay assignments set by your tutors can often seem rather complex. Understanding the question is essential to ensure that the essay you submit for assessment actually answers the question asked. The secret to answering an essay question is to start by identifying and understanding the key 'instruction words' within the question.

Below are three examples of essay questions set by the tutors on modules TSM09101 (Hospitality Business Development) and TSM09106 (Food \& Wine in Society) in academic year 2009/10. The key instruction words in each question have been highlighted and underlined. 
"Hospitality managers and marketers need relevant, accurate, current and reliable information to be able to make effective decisions about the future of the business" (Bowie \& Buttle, 2004). Critically evaluate this point of view within the context of a type of hospitality business of your choice.

Discuss how eating and drinking habits and cuisine styles (either in the UK or in your native country) have been influenced by factors such as immigration, travel, and the media.

Investigate why restaurants close down in the UK at the rate of one per two weeks.

In the activity below, match each 'instruction word' in the left-hand column by writing the appropriate word in the relevant box in the middle column. When you have finished, read the feedback for this activity in the Student Feedback Guide.

\begin{tabular}{|c|l|l|}
\hline \multicolumn{2}{|c|}{ Instruction Words } & Meaning \\
\hline \multirow{4}{*}{$\begin{array}{c}\text { Evaluate } \\
\text { Illustrate }\end{array}$} & Examine in detail \\
\cline { 2 - 3 } Outline & Consider the evidence or arguments and make a \\
Analyse & judgement about the merits, point out faults \\
\cline { 2 - 3 } $\begin{array}{l}\text { Criticise } \\
\text { Discuss }\end{array}$ & Explain and give different views about something, then \\
& give your own opinion based on sound evidence \\
\cline { 2 - 3 } & Examine the evidence and decide on the value of \\
\cline { 2 - 3 } & something, make a judgement about it, based on sound \\
\cline { 2 - 3 } & evidence \\
\hline
\end{tabular}

\section{Students Say...}

Read what Krish has to say about understanding the question...

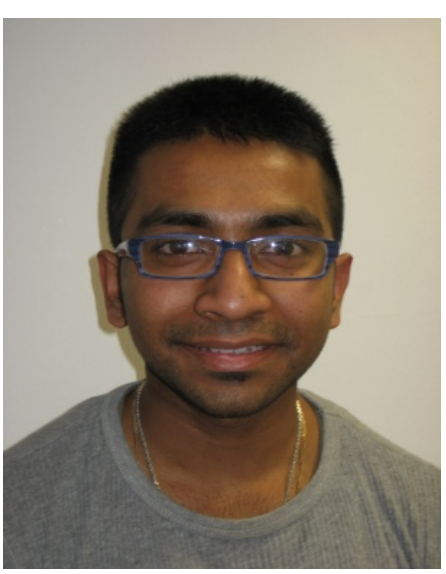

Krish

\author{
Krish says: \\ "When I came over here, I learned how to read \\ essay questions. So, every time we are told to \\ read the question properly so you know which are \\ your key words, and once you consider the \\ question properly, you can understand by \\ yourself these are the specific words."
}

\section{Presentation skills}

\section{Presentation assessment criteria}

All students on the BA Hospitality Management study programme will give oral presentations as part of the assessment process. It is important that you find out in advance what assessment criteria will be used. This will help you to plan and give a more effective presentation.

Some possible assessment criteria are listed below with descriptions of what is expected for each one.

\begin{tabular}{|l|l|}
\hline $\begin{array}{l}\text { Presentation Assessment } \\
\text { Criteria }\end{array}$ & What does this involve? \\
\hline Teamwork & $\begin{array}{l}\text { Division of material amongst the group members. Evidence of group } \\
\text { practice. }\end{array}$ \\
\hline
\end{tabular}




\begin{tabular}{|l|l|}
\hline $\begin{array}{l}\text { Presentation Assessment } \\
\text { Criteria }\end{array}$ & What does this involve? \\
\hline Organisation & $\begin{array}{l}\text { Division of material amongst the group members. Evidence of group } \\
\text { practice. }\end{array}$ \\
\hline Argumentation & Clear research focus. Good selection of ideas and evidence used. \\
\hline Language Accuracy & Appropriate structure and vocabulary used. \\
\hline Research & $\begin{array}{l}\text { Evidence of research having been undertaken. Appropriateness of } \\
\text { choice of sources. }\end{array}$ \\
\hline Clarity of communication & $\begin{array}{l}\text { Clear explanations of technical terms used clear, with clear } \\
\text { pronunciation. }\end{array}$ \\
\hline Content & $\begin{array}{l}\text { Appropriateness of both the amount and the level of the materials } \\
\text { used. }\end{array}$ \\
\hline Visual Aids & Used to support the message of the presentation. \\
\hline Academic Requirements & Appropriate register, and acknowledgement of sources. \\
\hline
\end{tabular}

Below are the assessment criteria that were used during academic year 2009/10 for the group oral presentation assignment given to students to assess the team's performance on the TSM09107 Live Project study module.

\section{TSM09107 Live Project: Oral Presentation Assessment Criteria Quality of oral and visual communication and delivery; Ability to make a professional persuasive business pitch as a team; Choice and clarity of content; Introduction and conclusion to presentation; Ability to answer questions}

\section{Students Say...}

Read Sumit's thoughts on how presentations help to build your confidence...

\section{Sumit Says:}

"In presentation I try to think about positives only, not negatives because this makes you increase your confidence in you. And we learn from mistakes, we make mistakes once and even second time. By the third time, you are perfect in that. My tutors taught me how to look at my mistakes in a good way."

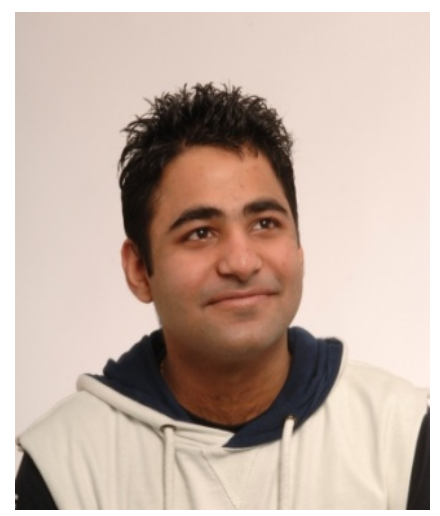

Sumit

\section{How effective is SPICE?}

Early results suggest that students who have used SPICE are more confident about their studies, have more specific expectations about their new learning and teaching context, approach tutors for help more readily rather than wait until problems arise, show a positive 
attitude towards attending lectures and participating in tutorials, and perform better in assessments (In order to sustain this claim, academic results are going to be examined at the end of 2010/11 academic year). Overall, there is a marked difference in students' approach to learning after using SPICE. Anecdotal evidence from working closely with the programme team confirms the benefits. A survey of tutors on the programme who work with students who completed SPICE is planned to take place in Autumn 2011 to ascertain these claims.

The tutors in India who work with students during the preparation for study at Edinburgh Napier were asked for their opinions about SPICE and its effectiveness. All twelve tutors commented on the usefulness of SPICE to introduce students to life and study at Edinburgh Napier and pointed to the high value of students being able to consider their current study skills and develop effective skills for study at Edinburgh Napier.

Tutors and students in India offered some suggestions for the contents including more information about Edinburgh and the university; a range of student voices, not just Indian students, tasks covering more skills, and a link to a social network to enhance communication between students in Edinburgh and India. Some of the suggestions were subsequently included in SPICE. The wider range of student voices, tasks, and a link to a social network will be included in the final version of SPICE.

The one concern expressed by the tutors was about finding time to use SPICE with students. In the Indian context, students have classes from 9 am to 5 pm every day, with no space left for additional activities. Two solutions were put forward to either (1) shorten the duration of some of the classes to fit one 2 hour class weekly based on SPICE throughout year 2 or (2) to teach SPICE in trimester 2 of year 2 (May - September) when the teaching workload is not as heavy. As a result, a 2 hour weekly class called 'Effective Study Skills' has been added to the trimester 2 timetable. It has been co-designed by colleagues from Edinburgh Napier and colleges in India to ensure there are realistic expectations about what can be achieved. 


\section{Learning points}

The key success of SPICE is in working very closely with students and tutors in Edinburgh Napier University and colleges in India to establish the core skills the students need to succeed in their study. The students were encouraged to contribute actively to the contents of the resource by giving their opinions about what should be included, the main challenges they faced and the solutions they developed. The students chose the main parts of SPICE, they were asked to sample the activities and give feedback, choose the pictures for SPICE and even the name of the resource. The students frequently commented on the value of 'being involved' in a university project.

\section{Ways forward}

SPICE was a pilot and the feedback from the project will enable the development of the final resource for all international and direct entry students from colleges. SPICE is not a new initiative and not the only initiative of such kind in UK HE. However, through careful work with students and programme teams, lessons from the pilot and stress on developing skills, SPICE promises to be an effective pre-arrival support resource.

Currently SPICE is hosted and operated within Edinburgh Napier University therefore login to SPICE cannot be shared. Work is under way to upgrade the interface and functionality of SPICE to make it more user-friendly and to enable better tracking of student progress. Additionally, a wider range of student voices and tasks, expanding the core and subject specific skills and including a social network link to Napier Facebook are being developed. It is hoped that the outcome will be two parallel streams of SPICE: International and College. This work is due to be completed by April/May 2011.

Further work may include developing a postgraduate route to attract other groups of students. Also, work with students to evaluate and provide comments on the resource is planned for 2011. This would also help further enhance the student-led feature of SPICE. 


\section{References}

Burley, K., Walton, J.R., and Uruchurtu, E. (2009) Enhancing the learning experience of post-graduate students from the Indian Sub-Continent. Available at: http://www.eair.nl/forum/vilnius/pdf/601.pdf (Accessed: 7 February 2011).

Cook, A., Macintosh, K.A. and Rushton, B.S. (eds.) (2006) Supporting students: early induction. Coleraine: University of Ulster.

Edinburgh Napier University (2007) Annual review 2007. Edinburgh: Edinburgh Napier University.

Edinburgh Napier University (2008) Facts \& figures 2009/2010. Available at: http://www.napier.ac.uk/aboutus/factsandfigures/Documents/Facts\%20Figures\%20 2009-10.pdf (Accessed: 7 February 2011).

Edward, N.S. (2003) 'First impressions last: an innovative approach to induction', Active Learning in Higher Education, 4(3), pp.226-42.

Higher Education Statistics Agency (HESA) (2010) Students in higher education institutions 2008/09. Press release 144. Available at: http://www.hesa.ac.uk/index.php?option=com content\&task=view\&id=1668\&ltemid =161 (Accessed: 7 February 2011).

Huczynski, A. and Buchanan, D. (2007) Organizational behaviour. $6^{\text {th }}$ edn. Harlow: Prentice Hall.

Lowe, H. and Cook, A. (2003) 'Mind the Gap: Are Students Prepared for Higher Education', Journal of Further and Higher Education, 27(1), pp.53-76.

Murphy, J. (2008) 'Designing an induction programme for a blended learning postgraduate program in health informatics', IMIA Conference: Building Worldwide Capacity for the Health Informatics Workforce. Buenos Aires, Argentina 27-28 October. 
Palloff, R.M. and Pratt, K. (2007) Building online communities: effective strategies for the virtual classroom. San Francisco: John Wiley and Sons, Inc.

Patricia, A. and Dawson, C. (2004) The induction needs of international students at postgraduate level. Available at:

http://www.llas.ac.uk/materialsbank/mb080/LO 3/lord business sc.pdf (Accessed: 7 February 2011).

Pringle, G., Fischbacher, M. and Williams, A. (2008) Assisting international Students to manage their transition to UK academic culture. Available at: http://www.universitas21.com/TandL/Papers/Thu3.pdf (Accessed: 7 February 2011).

Shofield, M. and Sackvile, A. (2006) Student induction - from event to entitlement. Available at:

http://www.edgehill.ac.uk/solstice/researchanddissemination/documents/Studentind uction-fromeventtoentitlement2005.pdf (Accessed: 7 February 2011).

Watson, J. (2008) 'Enhancing the experience of the international student: a pre-arrival online preparatory course, blending technologies and introducing life and study in the UK', Proceedings of the Third International Blended Learning Conference. Hatfield, UK 18-19 June. University of Hertfordshire, pp. 124-131.

White, S.A. and Carr, L.A. (2005) Brave new world: can we engineer a better start for Freshers?', Frontiers in Education 2005. Proceedings of the $35^{\text {th }}$ Annual Conference. Indianapolis 19-22 October, pp. 26-31.

\section{Author details}

Dr Monika Foster is a Senior Lecturer and Senior Teaching Fellow at Edinburgh Napier University. She was awarded the title of Visiting Professor by Shandong University of Finance in China. Her research interests lie in enhancing the international student experience and collaborative research partnerships overseas. Email: m.foster@napier.ac.uk. 